\title{
Effects of Liquid Whey Protein Concentrate on Functional and Sensorial Properties of Set Yogurts and Fresh Cheese
}

\author{
Marta H. F. Henriques • David M. G. S. Gomes • \\ Carlos J. D. Pereira • Maria H. M. Gil
}

Received: 18 August 2011 / Accepted: 2 January 2012 /Published online: 17 January 2012

(C) Springer Science+Business Media, LLC 2012

\begin{abstract}
The production and incorporation of liquid whey protein concentrates (LWPCs) in fresh cheese and set yogurt is proposed as a solution for immediate reutilization of whey produced by small- and medium-scale dairy plants avoiding expensive processing steps (e.g., evaporation and drying) for the recovery of this by-product. Accordingly, the incorporation of LWPCs in such products was performed in order to compare the functional and sensorial properties of modified products with the conventional ones. The use of LWPC in fresh cheese increased water-holding capacity as well as product stability during storage. Fresh cheese hardness, chewiness, and gumminess decreased during storage in a more pronounced way in products with LWPC. The fat content influences significantly all the physicochemical properties tested in set yogurts. Incorporating LWPC in set yogurts does not produce appreciable differences in the visual properties when considering products with medium-fat content, but these
\end{abstract}

M. H. F. Henriques $(\bowtie) \cdot$ D. M. G. S. Gomes • C. J. D. Pereira

Escola Superior Agrária de Coimbra-Department of Food

Science and Technology,

Polytechnic Institute of Coimbra, Bencanta,

3040-316 Coimbra, Portugal

e-mail: mhenriques@esac.pt

D. M. G. S. Gomes

e-mail: david@esac.pt

C. J. D. Pereira

e-mail: cpereira@esac.pt

M. H. F. Henriques • M. H. M. Gil

CIEPQPF, Chemical Engineering Department,

Faculty of Science and Technology, University of Coimbra,

Rua Sílvio Lima-Pólo II,

3030-790 Coimbra, Portugal

M. H. M. Gil

e-mail: hgil@eq.uc.pt differences become significant for full-fat yogurts. Adhesiveness and springiness were not significantly affected with storage time or by the amount of LWPC incorporated for medium-fat yogurts. Higher values of hardness and gumminess were obtained for full-fat yogurts, but these parameters decreased with LWPC incorporation. Syneresis was reduced using LWPC but increased with storage time. During storage, viscosity differences between LWPC incorporated yogurts and the conventional ones were only maintained in the case of creamy yogurts. The sensory panel detected differences between conventional and modified products in the case of fresh cheeses but no significative differences were detected between yogurts. LWPCs can be a good alternative to conventional dry products used in fresh cheese and set yogurt manufacture since their utilization reduces milk consumption and allows for the increase in total solids content. Additionally, their incorporation in milk originates end products with attractive physicochemical and sensorial characteristics at lower production costs.

Keywords Whey protein - Set yogurt . Fresh cheese . Texture, viscosity, syneresis, sensorial properties

\section{Introduction}

The industrial production of cultured dairy products such as fresh cheese and yogurt, involves the standardization of solids in milk, in order to prevent the spontaneous separation of whey (currently called syneresis) that is seen as a drawback for these products (Lucey 2004; Amatayakul et al. 2006). This operation is normally performed in a mix tank under properly agitation, where the various normally dry ingredients (conventional ingredients) are added to milk. For fresh cheese production, skimmed milk powder is often used (Lucey 2002). Although, products such as whole milk 
powder, caseinates, or whey protein concentrate (WPC) are also employed for yogurt manufacture (Tamine and Robinson 1999), the use of liquid whey protein concentrates (LWPCs) is not mentioned. The latter procedure allows for internal reutilization of whey in small- and medium-scale dairy plants reducing thus the need for external acquisition of dry ingredients.

Whey protein concentrate powders (WPC) are largely used as attractive food ingredients in a wide range of food applications (Diaz et al. 2009), especially due to their specific functional and nutritional properties. The production of bovine WPCs or whey protein isolates (WPI) is usually associated to large-scale production plants. For economical reasons, smaller dairy industries cannot apply the same strategy what may result in difficulties for whey disposal or reutilization. However, the increasing environmental constraints oblige them to look at whey not as a residue but as a valuable by-product for internal valorization. This perspective can simultaneously improve production yields and may add nutritional and functional value to their existing products.

The integration of an ultrafiltration/diafiltration (UF/DF) section in small- and medium-scale dairy industrial plants is considered economically feasible for producing LWPC and LWPI which, in turn, could be usefully incorporated in traditional products, namely cheeses. Several authors refer to this possibility (Abrahamsen 1979; Banks and Muir 1985; Baldwin et al. 1986; Korolczuk and Mahaut 1991a, b; Mahaut and Korolczuk 1992; Smithers et al. 1996; Jameson and Lelievre 1996; Pérez-Munuera and Lluch 1999; Hinrichs 2001). The main topics and conclusions of such works were related to: (1) the importance of whey proteins denaturation in order to guarantee their contribution to the protein matrix of the cheese; (2) the importance of the dimensions of the denatured aggregates; (3) the increased water-holding capacity of cheese curds; (4) the lower acidification of modified products as a result of the higher buffering capacity of whey proteins; (5) the occurrence of differences in flavor of the modified products; and (6) the optimal amount of LWPC incorporable. In the production of yogurts, the utilization of LWPCs is nearly non-existent. Most of the published studies only evaluate the influence of WPC powders on chemical, functional, rheological, textural, and sensorial characteristics of liquid or set yogurts (Guzmán-González et al. 1999; Sodini et al. 2005, 2006; Damin et al. 2009; Herrero and Requena 2006; Cais-Sokolinska and Pikul 2006).

Although the use of LWPCs in small and medium dairy industrial plants appears to be quite promising, its use and performance on functional and sensorial characteristics of the resulting new products are too little considered by the research related to the dairy industry; for this reason the purpose of this work.

\section{Materials and Methods}

\section{LWPC Manufacture}

Bovine cheese whey was supplied by Queijaria Serqueijos SA (Portugal), obtained immediately after production, and transported to the pilot plant in 50-L jars. After reception, the whey was first filtered, analyzed, and then processed at $24-30^{\circ} \mathrm{C}$ to obtain the required amount of LWPC by using an UF pilot plant equipped with an organic DSS ${ }^{\mathrm{TM}}$ membrane, model $20 \mathrm{~K}$ $3838-30,5.5-\mathrm{m}^{2}$ filtering area, and $20 \mathrm{kDa}$ cutoff. During ultrafiltration with a volumetric concentration factor of 20 , the trans-membrane pressure was held at 3.7-4.0 bar. After concentration, the retentate was submitted to a thermal treatment $\left(90^{\circ} \mathrm{C} / 60 \mathrm{~s}\right)$ to achieve whey protein denaturation, cooled to $65^{\circ} \mathrm{C}$ and homogenized at 100 bar in order to reduce the diameter of the thermally induced aggregates to a value bellow $10 \mu \mathrm{m}$. This procedure was undertaken to avoid the disturbance of the casein matrix caused by large particles as pointed out by Walstra and van Vliet (1991) and Lebeuf et al. (1998). Before its incorporation in milk batches, for fresh cheese or yogurt production, the LWPC was analyzed and frozen at $-15^{\circ} \mathrm{C}$.

\section{Fresh Cheese Manufacture}

In the production of fresh cheese, three formulations were tested. For each formulation, bovine standardized milk was partially skimmed, pasteurized, and mixed with: (1) $4 \mathrm{~g} / 100 \mathrm{~g}$ of skimmed milk proteins (with about $50 \mathrm{~g}$ of proteins/100 g of powder) (Tecnilac-Portugal)—conventional process (C); (2) $25 \mathrm{~g} / 100 \mathrm{~g}$ (25LWPC), and (3) $50 \mathrm{~g} / 100 \mathrm{~g}$ (50LWPC) of bovine LWPC. In each trial, the fat content was normalized at $3.3 \mathrm{~g} / 100 \mathrm{~g}$. Batches of each formulation where pasteurized at $72{ }^{\circ} \mathrm{C}$ for $30 \mathrm{~s}$ and then fastly cooled to the coagulation temperature $\left(33^{\circ} \mathrm{C}\right)$. Coagulation was performed during $20 \mathrm{~min}$ in the presence of $200 \mathrm{mg} / \mathrm{L} \mathrm{CaCl}{ }_{2}$ solution $(51 \mathrm{~g} / 100 \mathrm{~mL})$ (Enzilab-Portugal), and $70 \mathrm{mg} / \mathrm{L}$ of rennet (>96\% chimosin) (Tecnilac-Portugal) previously diluted in tap water. After cutting the curd and drainage of the whey, fresh cheeses (of ca. $100 \mathrm{~g}$ ) were molded in plastic packages and maintained at $4 \pm 2{ }^{\circ} \mathrm{C}$ during storage (7 days).

\section{Set Yogurt Manufacture}

Two trials of yogurts were produced with skimmed bovine milk, with posterior fat normalization to 1.5 and $9 \mathrm{~g} / 100 \mathrm{~g}$ with cream. Three formulations with $1.5 \mathrm{~g} / 100 \mathrm{~g}$ of fat were normalized in dry matter contents $(15 \mathrm{~g} / 100 \mathrm{~g})$ and prepared: (1) with skim milk powder (conventional yogurt) (1.5-C), with (2) $15 \mathrm{~g} / 100 \mathrm{~g}$ (1.5-15LWPC), and (3) $30 \mathrm{~g} / 100 \mathrm{~g}$ (1.5-30LWPC) LWPC addition. 
In the case of full-fat yogurts ( $9 \mathrm{~g} / 100 \mathrm{~g}$ of fat), the dry matter content was set at $19 \mathrm{~g} / 100 \mathrm{~g}$ and the incorporation of LWPC was $30 \mathrm{~g} / 100 \mathrm{~g}$. The conventional product was denominated as (9-C) and the tested one as (9-30LWPC).

All the ingredients for each formulation were mixed, homogenized at 200 bar and pasteurized at $92{ }^{\circ} \mathrm{C} / 30$ seconds. Before filling and packaging, the mixture was stirred during 20 min at $43{ }^{\circ} \mathrm{C}$ and inoculated with a mixed culture of Lactobacillus bulgaricus and Streptococcus thermophilus (Ezal YO-MIX 601). The fermentation step was performed in $125-\mathrm{mL}$ polystyrene cups at constant temperature of $43 \pm 1{ }^{\circ} \mathrm{C}$ until the yogurt $\mathrm{pH}$ reached the value of $4.6 \pm 1$. The yogurts were then stored at $4 \pm 2{ }^{\circ} \mathrm{C}$ after cooling during $1 \mathrm{~h}$.

\section{Chemical Analyses}

The biochemical composition of whey, LWPC, milk, skimmed milk protein, and cream was evaluated using the Portuguese Standards Methods (IPQ 1990) and the Official Analytical Methods (AOAC 1997). The samples of each formulation product were collected using the Portuguese specific standard procedure for dairy products (NP 4146:1991). In the case of fresh cheese and set yogurt analyses, three samples at random were selected. However, if the evaluated parameter demanded homogeneous samples (such as cheese chemical composition) an homogenizer (Masticator IUL Instruments) was used.

pH was determined with a $\mathrm{pH}$ meter HI 9025 HANNA Instruments, immediately after production and later during the storage time. Titrable acidity, expressed as a percentage of lactic acid, was determined by titration using $0.1 \mathrm{~N}$ $\mathrm{NaOH}$ solution by the technique described in NP 470/1983 for milk, AOAC (1997) for whey, LWPC and cheese, and NP 701:1982 for yogurts.

Total solids were determined by oven drying the samples according to NP 580:1970 for milk, AOAC (1997) for LWPC, NP 3544:1987 for cheese, and NP 703:1982 for yogurt. Ash content was performed by incineration of dry samples in an electric muffle furnace (Nabertherm, model LE 4/11/R6) by the AOAC methods (1997).

The fat content of milk, LWPC, and products formulations was determined by the Gerber method (NP 469:2002) adapted to each product and specific for yogurt (NP 1923:1987). In the case of fresh cheese, the Van Gulik method was used (NP 2105:1983).

The total $\mathrm{N}$ content was determined using the Kjeldahl method according to AOAC (1997). Total protein was estimated by multiplying the total nitrogen content of the samples by a factor of 6.38 .

The lactose concentration was determined by difference between the dry mass of the sample and the sum of the remaining components (ash, fat, and protein). All the analyses were made in triplicate.
Physicochemical Analyses of Fresh Cheese and Set Yogurt

\section{Color}

Color was determined in triplicate with a colorimeter Minolta Chroma Meter, model CR-200B, using the L*a*b* CIELAB system calibrated with a white standard dish (CR-A47).

\section{Syneresis}

Cheese spontaneous syneresis was calculated as the ratio between the mass of serum lost spontaneously during 6 days of storage and the original mass of the cheese in normal cooling conditions $\left(<6{ }^{\circ} \mathrm{C}\right)$. This analysis was performed using six fresh cheese samples chosen randomly.

Yogurt syneresis index (water retention capacity) followed the method described by Gauche (2007). Triplicate samples of $20 \mathrm{~g}$ were centrifuged at $350 \times \mathrm{g}$ in a refrigerated centrifuge (Hettich, model Rotanta 460R) during $10 \mathrm{~min}$ at $5{ }^{\circ} \mathrm{C}$. The supernatant was collected and weighed. The syneresis index (percent) was the proportion of the supernatant mass on the total mass sample multiplied by 100 .

\section{Viscosity}

The evaluation of yogurt viscosity was performed in triplicate, at controlled temperature $\left(5 \pm 1{ }^{\circ} \mathrm{C}\right)$, during $10 \mathrm{~min}$ (30-s intervals), in a rotational Brookfield Viscometer, model DV II, with a concentric cylinder RV (spindle 3) at a constant angular velocity (2.5 rpm). Prior to the viscosity determination the refrigerated set yogurt samples were manually homogenized during $1 \mathrm{~min}$, and set to rest for $5 \mathrm{~min}$ in the fridge $\left(5 \pm 1^{\circ} \mathrm{C}\right)$. The viscosity of the samples was the mean value of the viscosity measurements during the $10 \mathrm{~min}$ of analysis.

\section{Textural Analysis}

A Stable Micro Systems Texture analyzer, model TA.XT Express Enhanced, was used to perform textural analysis $(n=3)$ and the results were calculated by the Specific Expression PC Software. For fresh cheese a texture profile analysis was run with a penetration distance of $15 \mathrm{~mm}$ at $1 \mathrm{~mm} / \mathrm{s}$ test speed, using an acrylic cylindrical probe with a diameter of $12.5 \mathrm{~mm}$ and height of $38.1 \mathrm{~mm}$. For set yogurts, the penetration distance was $20 \mathrm{~mm}$ at $2 \mathrm{~mm} / \mathrm{s}$ using a stainless steel cylindrical probe with a diameter of $25.4 \mathrm{~mm}$ and height of $38.1 \mathrm{~mm}$. The following parameters were quantified (Phadungath 2010): hardness (the peak force measured during the first compression cycle), adhesiveness (the negative force area for the first bite, representing the necessary work to pull the compression plunger away from 
the sample), cohesiveness (the ratio of the positive force area during the second compression to that during the first compression), springiness (the height that the sample recovers during the time that elapse between the end of the first cycle and the start of the second cycle), and gumminess (the product of hardness and cohesiveness). Additionally, for fresh cheese chewiness (the product of gumminess and springiness) was also quantified.

\section{Sensorial Analysis}

Sensorial analysis was based on preference and triangular tests performed by an untrained panel in order to detect differences between products with conventional formulations and LWPC incorporation. It was used a panel with 31 members for the preference test and for the two triangular tests performed in fresh cheese evaluations, and 35 participants for the three trials with set yogurts (two for medium-fat yogurts and one for full-fat yogurts). The triangular tests were based in Binomial distribution (ISO 8586-2 1994) with a confidence level at $p<0.05$.

\section{Statistical Analysis}

Statistical analysis of the data was carried out employing ANOVA package included in Statistica 8.0 (Hill and Lewicki 2007).

One-way ANOVA tests were performed to compare the means of gross composition of bovine whey and liquid whey protein concentrates shown in Table 1, and the gross composition of medium-fat and full-fat yogurts, presented in Table 4. The comparison was done employing a multiple comparison Tukey HSD test with a confidence level of $95 \%$.

Two-way ANOVA with interaction was employed to determine the effects of both storage time and LWPC incorporation on biochemical composition (Fig. 1), color (Table 2), and texture (Table 3) of fresh cheese.

Table 1 Gross chemical composition of bovine whey and liquid whey protein concentrate (LWPC): total solids, ash, fat, protein, lactose, and titratable acidity (TA)

\begin{tabular}{llr}
\hline$(\mathrm{g} / 100 \mathrm{~g})$ & Whey & \multicolumn{1}{l}{ LWPC } \\
\hline Total solids & $6.34 \pm 0.28 \mathrm{a}$ & $14.37 \pm 0.48 \mathrm{~b}$ \\
Ash & $0.50 \pm 0.03 \mathrm{a}$ & $0.41 \pm 0.03 \mathrm{a}$ \\
Fat & $0.60 \pm 0.04 \mathrm{a}$ & $4.45 \pm 0.64 \mathrm{~b}$ \\
Protein & $0.72 \pm 0.09 \mathrm{a}$ & $4.95 \pm 0.35 \mathrm{~b}$ \\
Lactose & $4.53 \pm 0.12 \mathrm{a}$ & $4.56 \pm 0.46 \mathrm{a}$ \\
TA (\% lactic acid) & $0.11 \pm 0.02 \mathrm{a}$ & $0.16 \pm 0.02 \mathrm{a}$ \\
\hline
\end{tabular}

Means of two batches

Means within the same rows without the same letters $(\mathrm{a}, \mathrm{b})$ are statistically different at $p=0.05$
The impact of three independent variables (storage time, LWPC incorporation, and fat content) in yogurts color, texture, syneresis, and viscosity was statistically analyzed with $\mathrm{N}$-way ANOVA (data not shown). Subsequently, whenever the impact of fat content was observed to be significant for all the parameters evaluated, the effect of storage time and LWPC incorporation was tested separately for medium-fat and full-fat yogurts employing two-way ANOVA with interaction. The results obtained are shown in Table 5 (color analysis), Table 6 (texture analysis), Fig. 3 and Table 7 (syneresis), and Fig. 4 and Table 7 (viscosity). All analysis were performed using Tukey's HSD post tests with $95 \%$ confidence level, corresponding to a critical $p=0.05$.

\section{Results and Discussion}

\section{Characterization of LWPC}

In about 30 min of ultrafiltration, $190 \mathrm{~L}$ of bovine whey were concentrated for the recovery of $9 \mathrm{~L}$ of retentate. As expected, the LWPC showed higher dry matter, fat, and total protein contents compared with the original whey (Table 1). However, the ca. 7 times increase for protein and fat, is not in accordance with the volumetric concentration factor. This difference can be explained by the following factors: protein losses in permeate throughout concentration due to the relatively high molecular weight (MW) membrane cutoff; losses of fat adhered in the membrane and equipment surfaces; and water incorporation in retentate during its recovery from the dead volume of the batch ultrafiltration equipment. As expected, the amounts of ash, lactose, and lactic acid achieved for whey were maintained in LWPC $(p>0.05)$ being the ca. 2.2-fold increase in total solids content of LWPC due chiefly to the increase in protein and fat contents.

The drawbacks pointed out concerning protein and fat recovery which originated lower production yields in LWPC, can be overcome by the reduction of the MW membrane cutoff and by the increase in the volumes processed minimizing the dilution effect referred.

Fresh Cheese Composition and Physicochemical Properties

Fresh cheese is a very perishable product with a limited shelf life (about 7 days). Figure 1 compares the biochemical composition of conventional fresh cheese and alternative products during storage. As expected, it is possible to observe that all the produced samples, show increases in total solids, fat, protein, and ash contents as a result of the loss of humidity among the storage period. At the first day of storage, total solids, fat, and protein concentrations were statistically different $(p<0.05)$ when comparing conventional and alternative products. The mineral content only differs 

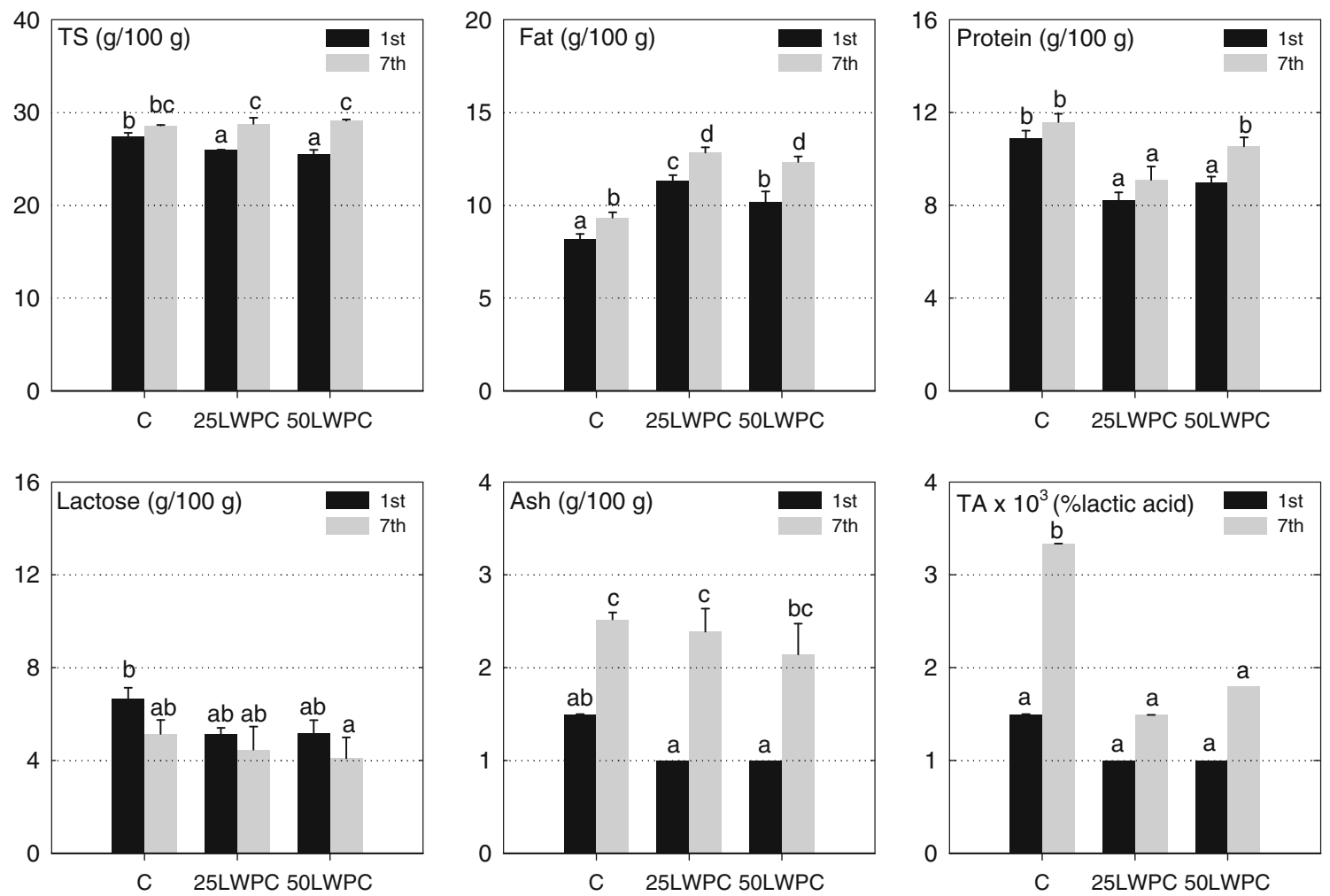

Fig. 1 Biochemical composition of fresh cheese during storage (first and seventh day). Total solids (TS), fat, protein, lactose, ash, and titratable acidity (TA) for: $C$ - conventional fresh cheese, $25 L W P C$ and $50 L W P C$ -

fresh cheese incorporated with LWPC ( 25 and $50 \mathrm{~g} / 100 \mathrm{~g}$ respectively). Different letters indicate significant differences $(p<0.05)$

Table 2 Color parameters $\left(\mathrm{L}^{*}, \mathrm{a}^{*}, \mathrm{~b}^{*}\right)$ of fresh cheese during storage; $p$ values of two-way ANOVA with factors interaction, for color parameters in fresh cheese

\begin{tabular}{|c|c|c|c|c|}
\hline \multirow[t]{2}{*}{ Color parameters $^{\mathrm{a}}$} & \multirow[t]{2}{*}{ Storage time (days) } & \multicolumn{3}{|l|}{ Fresh cheese } \\
\hline & & $\mathrm{C}$ & 25LWPC & 50LWPC \\
\hline \multirow[t]{2}{*}{$\mathrm{L}^{*}$} & 1 & $94.73 \pm 1.12 b c$ & $95.00 \pm 0.10 \mathrm{bc}$ & $95.30 \pm 0.30 \mathrm{c}$ \\
\hline & 7 & $92.30 \pm 0.82 \mathrm{a}$ & $93.47 \pm 0.15 \mathrm{ab}$ & $94.67 \pm 0.06 \mathrm{bc}$ \\
\hline \multirow[t]{2}{*}{$a^{*}$} & 1 & $-3.70 \pm 0.10 \mathrm{a}$ & $-2.97 \pm 0.15 b$ & $-3.50 \pm 0.20 \mathrm{a}$ \\
\hline & 7 & $-1.63 \pm 0.06 \mathrm{~d}$ & $-2.33 \pm 0.06 \mathrm{c}$ & $-2.73 \pm 0.15 b$ \\
\hline \multirow[t]{2}{*}{$b^{*}$} & 1 & $10.20 \pm 0.17 \mathrm{~b}$ & $10.03 \pm 0.15 \mathrm{~b}$ & $10.33 \pm 0.06 \mathrm{~b}$ \\
\hline & 7 & $12.77 \pm 0.06 \mathrm{c}$ & $10.30 \pm 0.10 \mathrm{~b}$ & $8.87 \pm 0.06 \mathrm{a}$ \\
\hline \multirow[t]{2}{*}{ Factors $^{\mathrm{b}}$} & & \multicolumn{3}{|c|}{ Color parameters } \\
\hline & & $\mathrm{L}^{*}$ & $a^{*}$ & $b^{*}$ \\
\hline \multicolumn{2}{|l|}{ Storage time (ST) } & 0.000 & 0.000 & 0.000 \\
\hline \multicolumn{2}{|l|}{ LWPC incorporation } & 0.003 & 0.000 & 0.000 \\
\hline \multicolumn{2}{|l|}{$\mathrm{ST} \times \mathrm{LWPC}$ incorporation } & 0.062 & 0.000 & 0.000 \\
\hline
\end{tabular}

Different letters $(\mathrm{a}, \mathrm{b}, \mathrm{c})$ indicate significant differences $(p<0.05)$ for each color parameter; $p<0.05$ (in italics) indicates that factors produce statistically significant differences in dependent variables

$C$ conventional fresh cheese, $25 L W P C$ fresh cheese with $25 \mathrm{~g} / 100 \mathrm{~g}$ LWPC incorporation, $50 L W P C$ fresh cheese with $50 \mathrm{~g} / 100 \mathrm{~g}$ LWPC incorporation

${ }^{a}$ Color parameters $\left(L^{*}, a^{*}, b^{*}\right)$ of fresh cheese during storage

${ }^{\mathrm{b}} p$ values of two-way ANOVA with factors interaction, for color parameters in fresh cheese 
Table 3 Texture parameters (hardness, adhesiveness, springiness, chewiness, and cohesiveness) of fresh cheese during storage; $p$ values of twoway ANOVA with factors interaction, for texture parameters in fresh cheese

\begin{tabular}{|c|c|c|c|c|c|c|}
\hline \multirow[t]{2}{*}{ Texture parameters ${ }^{\mathrm{a}}$} & \multirow[t]{2}{*}{ Storage time (days) } & \multicolumn{5}{|l|}{ Fresh cheese } \\
\hline & & $\mathrm{C}$ & 25LWPC & & 50LWPC & \\
\hline \multirow[t]{2}{*}{ Hardness } & 1 & $1.26 \pm 0.12 \mathrm{~b}$ & $1.38 \pm 0.08 \mathrm{~b}$ & & $1.73 \pm 0.12 \mathrm{c}$ & \\
\hline & 7 & $1.06 \pm 0.06 \mathrm{ab}$ & $0.88 \pm 0.16 \mathrm{a}$ & & $0.82 \pm 0.18 \mathrm{a}$ & \\
\hline \multirow[t]{2}{*}{ Adhesiveness } & 1 & $-2.91 \pm 0.12 \mathrm{c}$ & $-5.17 \pm 0.17 \mathrm{a}$ & & $-2.03 \pm 0.06 \mathrm{~d}$ & \\
\hline & 7 & $-2.64 \pm 0.16 \mathrm{c}$ & $-4.49 \pm 0.09 \mathrm{~b}$ & & $-2.65 \pm 0.10 \mathrm{c}$ & \\
\hline \multirow[t]{2}{*}{ Springiness } & 1 & $0.99 \pm 0.01 \mathrm{~b}$ & $0.99 \pm 0.01 \mathrm{~b}$ & & $0.99 \pm 0.00 \mathrm{~b}$ & \\
\hline & 7 & $0.92 \pm 0.01 \mathrm{a}$ & $0.99 \pm 0.01 \mathrm{~b}$ & & $0.99 \pm 0.00 \mathrm{~b}$ & \\
\hline \multirow[t]{2}{*}{ Chewiness } & 1 & $0.65 \pm 0.06 \mathrm{~cd}$ & $0.61 \pm 0.03 \mathrm{bcd}$ & & $0.78 \pm 0.05 \mathrm{~d}$ & \\
\hline & 7 & $0.50 \pm 0.03 \mathrm{abc}$ & $0.47 \pm 0.09 \mathrm{ab}$ & & $0.38 \pm 0.08 \mathrm{a}$ & \\
\hline \multirow[t]{2}{*}{ Gumminess } & 1 & $0.66 \pm 0.06 \mathrm{~cd}$ & $0.62 \pm 0.03 \mathrm{bcd}$ & & $0.79 \pm 0.05 \mathrm{~d}$ & \\
\hline & 7 & $0.55 \pm 0.04 \mathrm{abc}$ & $0.47 \pm 0.09 \mathrm{ab}$ & & $0.39 \pm 0.08 \mathrm{a}$ & \\
\hline \multirow[t]{2}{*}{ Cohesiveness } & 1 & $0.53 \pm 0.01 \mathrm{~cd}$ & $0.45 \pm 0.01 \mathrm{a}$ & & $0.45 \pm 0.01 \mathrm{a}$ & \\
\hline & 7 & $0.52 \pm 0.01 \mathrm{c}$ & $0.54 \pm 0.01 \mathrm{~d}$ & & $0.47 \pm 0.01 \mathrm{~b}$ & \\
\hline \multirow[t]{2}{*}{ Factors $^{\mathrm{b}}$} & Texture parameters & & & & & \\
\hline & Hardness & Adhesiveness & Springiness & Chewiness & Gumminess & Cohesiveness \\
\hline Storage time (ST) & 0.000 & 0.082 & 0.000 & 0.000 & 0.000 & 0.000 \\
\hline LWPC incorporation & 0.145 & 0.000 & 0.000 & 0.455 & 0.273 & 0.000 \\
\hline $\mathrm{ST} \times \mathrm{LWPC}$ incorporation & 0.001 & 0.000 & 0.000 & 0.006 & 0.004 & 0.000 \\
\hline
\end{tabular}

Different letters ( $\mathrm{a}, \mathrm{b}, \mathrm{c}, \mathrm{d})$ indicate significant differences $(p<0.05)$ for each texture parameter; $p<0.05$ (in italics) indicates that factors produce statistically significant differences in dependent variables

$C$ conventional fresh cheese, $25 L W P C$ fresh cheese with $25 \mathrm{~g} / 100 \mathrm{~g}$ LWPC incorporation, 50LWPC fresh cheese with $50 \mathrm{~g} / 100 \mathrm{~g}$ LWPC incorporation

${ }^{a}$ Texture parameters (hardness, adhesiveness, springiness, chewiness, and cohesiveness) of fresh cheese during storage

${ }^{\mathrm{b}} p$ values of two-way ANOVA with factors interaction, for texture parameters in fresh cheese

during the evaluated period but not between products. At the end of the storage time, no differences were found between both types of products in respect to the total solids content. The increase in protein content during storage was not statistically significant (with the exception in 50LWPC), whereas between products differences were found $(p<0.05)$, with lower values for fresh cheese with LWPC incorporation. After 7 days of storage, the lactic acid content (TA) was significantly lower for products with LWPC. The lower acidity of modified products can be attributed to the higher buffering capacity of whey proteins incorporated in the cheese matrix. For sensorial purposes, this aspect may be very interesting, because one of the main defects in the last days of storage of fresh cheese was the evidence of sour taste.

The yields achieved in this work for LWPC incorporated cheeses were lower than the ones obtained for the conventional product (Fig. 2). The pointed reasons for that can be the nature and relative proportion of proteins present in each formulation (caseins in conventional products and whey proteins in the tested ones). However, the use of LWPC in fresh cheese increased water-holding capacity. As a consequence, the products with LWPC showed higher stability during storage time and the differences in cheese yield between the first and seventh day were less evident in these products than in the conventional ones. These results are in agreement with those published by Jorge et al. (2006) for ripened cheese with 10 and $20 \mathrm{~g} / 100 \mathrm{~g}$ of

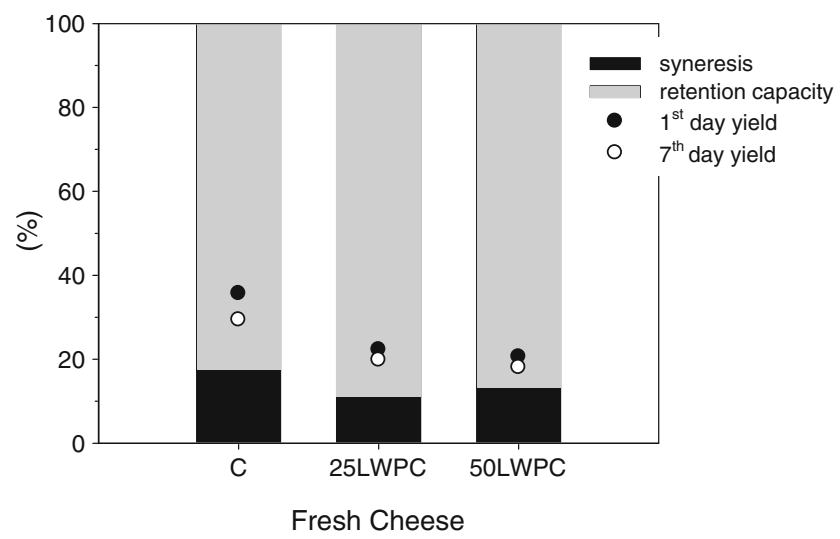

Fig. 2 Spontaneous syneresis, retention capacity, and cheese yield at first and seventh storage day for conventional and LWPC incorporated fresh cheeses. $C$ - conventional fresh cheese $25 L W P C$ and $50 L W P C-$ cheese incorporated with LWPC (25 and $50 \mathrm{~g} / 100 \mathrm{~g}$ respectively) 
LWPC incorporation. Jameson and Lelievre (1996) studied the effects of whey protein incorporation in the characteristics of cheeses and concluded that they were highly influenced at chemical, biochemical, and biophysical levels depending on if the proteins were in its native state or denatured. Abrahamsen (1979) reported increases between $1 \%$ and $17 \%$ in ripened cheese yields, with denatured whey proteins incorporated at 2.5 to $10 \mathrm{~g} / 100 \mathrm{~g}$ when compared to ripened cheese without proteins addition. Banks and Muir (1985) referred increases of $7 \%$ for Cheddar cheese. Punidadas et al. (1999) concluded that the homogenization of denatured whey proteins improves fat retention, because it promotes the fat dispersion in the cheese matrix favoring the interactions between proteins and lipids.

Table 2 shows the color parameters of fresh cheese over the storage time and their corresponding statistical analysis results. During the 7 days of storage all samples undergone a slight darkening (lower $\mathrm{L}^{*}$ values). However, increasing LWPC incorporation, decreased cheese darkening leading to a better product appearance (Table 2a). There were also observed significative differences in $\mathrm{a}^{*}$ and $\mathrm{b}^{*}$ values both during storage and with LWPC incorporation (Table 2b) demonstrating the importance of these two factors in the appearance of fresh cheese.

The textural results obtained are presented in Table 3a. Hardness, chewiness, and gumminess were similar between control and tested samples and decreased during storage (Table $3 b$ ). The results obtained are generally in agreement with the ones referred by Punidadas et al. (1999), who concluded that reduced fat cheeses made with homogenized whey proteins were similar to the control in terms of physical properties. Adhesiveness was not affected with time whereas springiness and cohesiveness were statistically different for both factors evaluated $(p<0.05)$.

Despite some texture, parameters were not significantly different between conventional and modified products differences were detected by the sensory panel for fresh cheese products, at a confidence level of 5\% in the triangular test (21 right answers for the tests between conventional cheese
(C) and 25LWPC and 24 right answers for 50LWPC; in both cases higher than 16 minimum right answers to validate each test). In the preference test between conventional cheese (C) and the one with $25 \mathrm{~g} / 100 \mathrm{~g}$ of LWPC (25LWPC), panelists evaluated better the second formulation, mentioning that this cheese type was softer. It is believed that the proportion of whey proteins and caseins in formulations is the key factor to simultaneously improve cheese sensorial characteristics and production yields. With appropriate modifications in the production technique both objectives can be optimized.

\section{Set Yogurt Composition and Physicochemical Properties}

Gross composition, TA, and $\mathrm{pH}$ of bovine medium-fat and full-fat yogurt are listed in Table 4. Full-fat yogurts present a lower total protein concentration. Their higher content in total solids is due exclusively to the percentage of fat in the formulation. No significant differences $(p>0.05)$ were observed in total solids, fat, and $\mathrm{pH}$ between each type of conventional yogurts (1.5-C and 9-C) and samples with whey proteins incorporation (1.5-15LWPC, 1.5-30LWPC, and 9-30LWPC). Protein concentration increased in alternative products, but the ash content was similar in all samples. During storage, $\mathrm{pH}$ and titrable acidity varied significantly $(p<0.05)$. Yogurts which presented a lower acidity were those who had higher levels of protein, presumably due to their buffering capacity. Salaün et al. (2005) and Kailasapathy et al. (1996) mentioned that substitution of part of the skim milk powder by whey proteins increases buffering capacity at $\mathrm{pH} 4$ and decreases buffering capacity between $\mathrm{pH} 5$ and 6 .

The statistical evaluation evidenced the influence of fat content in the physicochemical properties of yogurt, leading to the conclusion that this factor produces statistically significant differences in the evaluated properties. Hence, a factorial-ANOVA analysis for each kind of yogurt (medium fat and full fat) was performed where the independent variables were the storage time and the amount of LWPC incorporated in samples.

Table 4 Gross chemical composition of medium-fat and full-fat yogurt: total solids, ash, fat, protein, lactic acid, and $\mathrm{pH}$

\begin{tabular}{lrrrrr}
\hline Composition $(\mathrm{g} / 100 \mathrm{~g})$ & \multicolumn{1}{l}{ Yogurts } & & & \\
\cline { 2 - 6 } & \multicolumn{1}{l}{$1.5-\mathrm{C}$} & $1.5-15 \mathrm{LWPC}$ & $1.5-30 \mathrm{LWPC}$ & $9-\mathrm{C}$ & $9-30 \mathrm{LWPC}$ \\
\hline Total solids & $13.98 \pm 0.12 \mathrm{a}$ & $13.76 \pm 0.08 \mathrm{a}$ & $13.61 \pm 0.06 \mathrm{a}$ & $17.81 \pm 0.2 \mathrm{~b}$ & $18.27 \pm 0.48 \mathrm{~b}$ \\
Ash & $0.98 \pm 0.01 \mathrm{c}$ & $0.93 \pm 0.01 \mathrm{~b}$ & $0.90 \pm 0.01 \mathrm{a}$ & $0.94 \pm 0.01 \mathrm{~b}$ & $0.96 \pm 0.01 \mathrm{c}$ \\
Fat & $1.43 \pm 0.03 \mathrm{a}$ & $1.38 \pm 0.06 \mathrm{a}$ & $1.41 \pm 0.03 \mathrm{a}$ & $8.81 \pm 0.08 \mathrm{~b}$ & $9.00 \pm 0.05 \mathrm{c}$ \\
Protein & $4.82 \pm 0.12 \mathrm{c}$ & $5.12 \pm 0.17 \mathrm{~d}$ & $5.43 \pm 0.44 \mathrm{~d}$ & $3.21 \pm 0.15 \mathrm{a}$ & $3.58 \pm 0.11 \mathrm{~b}$ \\
Lactic acid & $0.89 \pm 0.01 \mathrm{~b}$ & $0.91 \pm 0.01 \mathrm{c}$ & $0.87 \pm 0.01 \mathrm{a}$ & $0.89 \pm 0.01 \mathrm{~b}$ & $0.96 \pm 0.01 \mathrm{~d}$ \\
pH & $4.43 \pm 0.03 \mathrm{a}$ & $4.38 \pm 0.03 \mathrm{a}$ & $4.38 \pm 0.03 \mathrm{a}$ & $4.37 \pm 0.03 \mathrm{a}$ & $4.40 \pm 0.00 \mathrm{a}$ \\
\hline
\end{tabular}

Means within the same rows without the same letters (a, b, c, d) are statistically different at $p=0.05$

Medium-fat yogurts: $1.5-C$ conventional, $1.5-15 L W P C$ with $15 \mathrm{~g} / 100 \mathrm{~g}$ LWPC incorporation, 1.5-30LWPC with $30 \mathrm{~g} / 100 \mathrm{~g}$ LWPC incorporation; full-fat yogurts: 9-C conventional, 9-30LWPC with $30 \mathrm{~g} / 100 \mathrm{~g}$ LWPC incorporation 
Comparing conventional medium-fat yogurts with the ones produced with LWPC no significative differences in $\mathrm{L}^{*}$ and $\mathrm{a}^{*}$ color parameters were found (Table 5). However, in the case of full-fat yogurts higher $L^{*}$ values were observed and in this case the amount of whey proteins influences significantly $L^{*}$ and $b^{*}$ values (Table $5 b$ ). The storage time was not determinant in $b^{*}$ value for medium-fat yogurts and on $\mathrm{L}^{*}$ value for full-fat yogurts $(p>0.05)$.

The textural analysis (Table 6) did not show significative differences $(p>0.05)$ between medium-fat yogurt formulations for adhesiveness and springiness (Table 6b). On the contrary, hardness, gumminess, and cohesiveness differ statistically with the storage time and whey proteins incorporation. Higher values of hardness, adhesiveness, and gumminess were observed for full-fat yogurts than in the case of mediumfat yogurts. The presence of LWPC in 9-30LWPC formulation induced a reduction on these textural parameters comparing to the conventional product 9-C (Table 6a).
Figure 3 compares the syneresis of the different types of yogurts during storage. It is obvious that the significant reduction in syneresis with the use of LWPC and its increase during storage for both medium and full-fat yogurts (Table 7). The syneresis indexes obtained in this study for full-fat yogurts (9$\mathrm{C}$ and 9-30LWPC) are significantly lower than those reported by Guzman-Gonzalez et al. (1999), Sodini et al. (2005 and 2006), and Li and Guo (2006). Only values obtained for medium-fat yogurts (1.5-C, 1.5-15LWPC, and 1.5-30LWPC) are in the same order of magnitude of those presented by Li and Guo (2006). The wide range of syneresis outcomes found in literature may result from two types of factors: those related to the evaluation method and those related to the operating conditions during the yogurt production. For the first factor, Amatayakul et al. (2006) concluded that the syneresis index determination by different methods leads to completely different values and therefore also assesses different behaviors. While the siphon method evaluates the spontaneous separation of whey on the surface of the gel

Table 5 Color parameters $\left(\mathrm{L}^{*}, \mathrm{a}^{*}, \mathrm{~b}^{*}\right)$ of yogurts during storage; $p$ values of two-way ANOVA with factors interaction, for color parameters in yogurts

\begin{tabular}{|c|c|c|c|c|c|c|}
\hline \multirow[t]{2}{*}{ a) Color parameters } & \multirow[t]{2}{*}{ Storage time (days) } & \multicolumn{3}{|c|}{ Medium-fat yogurts } & \multicolumn{2}{|l|}{ Full-fat yogurts } \\
\hline & & $1.5-\mathrm{C}$ & 1.5-15LWPC & 1.5-30LWPC & 9-C & 9-30LWPC \\
\hline \multirow[t]{3}{*}{$\mathrm{L}^{*}$} & 1 & $92.97 \pm 0.47^{\mathrm{a}}$ & $93.17 \pm 0.40^{\mathrm{a}}$ & $93.20 \pm 0.79^{\mathrm{a}}$ & $96.03 \pm 0.06^{\mathrm{A}}$ & $95.40 \pm 0.26^{\mathrm{A}}$ \\
\hline & 10 & $92.80 \pm 0.69^{\mathrm{a}}$ & $92.10 \pm 0.36^{\mathrm{a}}$ & $92.40 \pm 0.70^{\mathrm{a}}$ & $95.87 \pm 0.12^{\mathrm{A}}$ & $95.47 \pm 0.61^{\mathrm{A}}$ \\
\hline & 20 & $92.83 \pm 1.50^{\mathrm{a}}$ & $90.53 \pm 1.86^{\mathrm{a}}$ & $92.33 \pm 0.40^{\mathrm{a}}$ & $95.83 \pm 0.25^{\mathrm{A}}$ & $95.17 \pm 0.38^{\mathrm{A}}$ \\
\hline \multirow[t]{3}{*}{$a^{*}$} & 1 & $-4.10 \pm 0.17^{\mathrm{a}}$ & $-4.17 \pm 0.06^{\mathrm{a}}$ & $-4.07 \pm 0.06^{\mathrm{ab}}$ & $-3.93 \pm 0.23^{\mathrm{A}}$ & $-3.67 \pm 0.15^{\mathrm{AB}}$ \\
\hline & 10 & $-3.77 \pm 0.06^{\mathrm{ab}}$ & $-4.00 \pm 0.10^{\mathrm{ab}}$ & $-3.90 \pm 0.10^{\mathrm{ab}}$ & $-3.50 \pm 0.10^{\mathrm{AB}}$ & $-3.40 \pm 0.10^{\mathrm{AB}}$ \\
\hline & 20 & $-3.67 \pm 0.21^{\mathrm{b}}$ & $-3.90 \pm 0.26^{\mathrm{ab}}$ & $-3.87 \pm 0.15^{\mathrm{ab}}$ & $-3.27 \pm 0.15^{\text {В }}$ & $-3.23 \pm 0.06^{\mathrm{B}}$ \\
\hline \multirow[t]{3}{*}{$b^{*}$} & 1 & $7.70 \pm 0.10^{\mathrm{a}}$ & $8.27 \pm 0.15^{\mathrm{a}}$ & $7.50 \pm 0.10^{\mathrm{a}}$ & $9.47 \pm 0.06^{\mathrm{B}}$ & $9.13 \pm 0.21 \mathrm{AB}$ \\
\hline & 10 & $7.73 \pm 0.15^{\mathrm{a}}$ & $8.43 \pm 0.35^{\mathrm{a}}$ & $7.57 \pm 0.15^{\mathrm{a}}$ & $9.37 \pm 0.12 \mathrm{AB}$ & $8.97 \pm 0.12^{\mathrm{A}}$ \\
\hline & 20 & $7.80 \pm 0.78^{\mathrm{a}}$ & $8.33 \pm 0.90^{\mathrm{a}}$ & $7.87 \pm 0.21^{\mathrm{a}}$ & $9.17 \pm 0.12 \mathrm{AB}$ & $8.93 \pm 0.15^{\mathrm{A}}$ \\
\hline
\end{tabular}

b) Factors

Medium-fat yogurts

Storage time (ST)

LWPC incorporation

ST $\times$ LWPC incorporation

Full-fat yogurts

Storage time (ST)

LWPC incorporation

$\mathrm{ST} \times \mathrm{LWPC}$ incorporation

Color parameters

$\mathrm{L}^{*} \quad \mathrm{a}^{*} \quad \mathrm{~b}^{*}$

$\begin{array}{lll}0.044 & 0.001 & 0.689 \\ 0.118 & 0.061 & 0.006 \\ 0.243 & 0.683 & 0.939 \\ & & \\ 0.518 & 0.000 & 0.025 \\ 0.004 & 0.072 & 0.000 \\ 0.757 & 0.375 & 0.577\end{array}$

Different letters indicate significant differences $(p<0.05)$. Small letters $(\mathrm{a}, \mathrm{b})$ : differences amongst each color parameter for medium-fat yogurts. Capital letters (A, B): differences amongst each color parameter for full-fat yogurts. $p<0.05$ (in italics) indicates that independent variables produce statistically significant differences in dependent variables

1.5-C conventional, 1.5-15LWPC with $15 \mathrm{~g} / 100 \mathrm{~mL}$ LWPC incorporation, 1.5-30LWPC with $30 \mathrm{~g} / 100 \mathrm{~mL}$ LWPC incorporation, 9-C conventional, 9-30LWPC with $30 \mathrm{~g} / 100 \mathrm{~mL}$ LWPC incorporation

${ }^{\text {a }}$ Color parameters $\left(\mathrm{L}^{*}, \mathrm{a}^{*}, \mathrm{~b}^{*}\right)$ of yogurts during storage

${ }^{\mathrm{b}} p$ values of two-way ANOVA with factors interaction, for color parameters in yogurts 
Table 6 Texture parameters (hardness, adhesiveness, springiness, and cohesiveness) of set yogurts during storage; $p$ values of two-way ANOVA with factors interaction, for texture parameters in yogurts

\begin{tabular}{|c|c|c|c|c|c|c|}
\hline \multirow[t]{2}{*}{ Texture parameters $^{\mathrm{a}}$} & \multirow[t]{2}{*}{ Storage time (days) } & \multicolumn{3}{|c|}{ Medium-fat yogurts } & \multicolumn{2}{|l|}{ Full-fat yogurts } \\
\hline & & $1.5-\mathrm{C}$ & 1.5-15LWPC & 1.5-30LWPC & $9-\mathrm{C}$ & 9-30LWPC \\
\hline \multirow[t]{3}{*}{ Hardness } & 1 & $0.92 \pm 0.005 \mathrm{a}$ & $0.99 \pm 0.005 \mathrm{ab}$ & $1.09 \pm 0.013 \mathrm{ab}$ & $2.59 \pm 0.015 \mathrm{~B}$ & $1.89 \pm 0.029 \mathrm{~A}$ \\
\hline & 10 & $1.13 \pm 0.189 \mathrm{ab}$ & $1.09 \pm 0.042 \mathrm{ab}$ & $1.18 \pm 0.018 \mathrm{~b}$ & $3.33 \pm 0.250 \mathrm{C}$ & $2.03 \pm 0.196 \mathrm{~A}$ \\
\hline & 20 & $1.08 \pm 0.148 \mathrm{ab}$ & $1.12 \pm 0.096 \mathrm{ab}$ & $1.18 \pm 0.018 \mathrm{~b}$ & $3.17 \pm 0.327 \mathrm{C}$ & $1.78 \pm 0.150 \mathrm{~A}$ \\
\hline \multirow[t]{3}{*}{ Adhesiveness } & 1 & $-1.59 \pm 0.21 \mathrm{a}$ & $-2.08 \pm 0.22 \mathrm{a}$ & $-2.47 \pm 0.12 \mathrm{a}$ & $-5.88 \pm 0.09 \mathrm{~B}$ & $-5.19 \pm 0.10 \mathrm{BC}$ \\
\hline & 10 & $-2.34 \pm 0.49 \mathrm{a}$ & $-2.27 \pm 0.35 \mathrm{a}$ & $-2.56 \pm 0.40 \mathrm{a}$ & $-7.88 \pm 0.84 \mathrm{~A}$ & $-4.45 \pm 0.43 \mathrm{C}$ \\
\hline & 20 & $-2.63 \pm 0.68 \mathrm{a}$ & $-2.16 \pm 0.21 \mathrm{a}$ & $-2.41 \pm 0.55 \mathrm{a}$ & $-7.03 \pm 0.11 \mathrm{~A}$ & $-4.40 \pm 0.04 \mathrm{C}$ \\
\hline \multirow[t]{3}{*}{ Springiness } & 1 & $0.96 \pm 0.01 \mathrm{a}$ & $0.97 \pm 0.01 \mathrm{a}$ & $0.98 \pm 0.01 \mathrm{a}$ & $0.97 \pm 0.01 \mathrm{~A}$ & $0.97 \pm 0.01 \mathrm{AB}$ \\
\hline & 10 & $0.98 \pm 0.01 \mathrm{a}$ & $0.97 \pm 0.01 \mathrm{a}$ & $0.97 \pm 0.02 \mathrm{a}$ & $0.98 \pm 0.01 \mathrm{AB}$ & $0.99 \pm 0.01 \mathrm{~B}$ \\
\hline & 20 & $0.97 \pm 0.02 \mathrm{a}$ & $0.98 \pm 0.01 \mathrm{a}$ & $0.98 \pm 0.01 \mathrm{a}$ & $0.99 \pm 0.01 \mathrm{AB}$ & $0.97 \pm 0.01 \mathrm{~A}$ \\
\hline \multirow[t]{3}{*}{ Gumminess } & 1 & $0.42 \pm 0.01 \mathrm{ab}$ & $0.40 \pm 0.01 \mathrm{a}$ & $0.47 \pm 0.01 \mathrm{ab}$ & $1.19 \pm 0.01 \mathrm{~B}$ & $0.83 \pm 0.00 \mathrm{~A}$ \\
\hline & 10 & $0.50 \pm 0.02 \mathrm{ab}$ & $0.46 \pm 0.03 \mathrm{ab}$ & $0.51 \pm 0.02 \mathrm{ab}$ & $1.45 \pm 0.01 \mathrm{C}$ & $0.90 \pm 0.02 \mathrm{~A}$ \\
\hline & 20 & $0.49 \pm 0.01 \mathrm{ab}$ & $0.48 \pm 0.03 \mathrm{ab}$ & $0.53 \pm 0.02 \mathrm{~b}$ & $1.42 \pm 0.02 \mathrm{C}$ & $0.82 \pm 0.02 \mathrm{~A}$ \\
\hline \multirow[t]{3}{*}{ Cohesiveness } & 1 & $0.46 \pm 0.01 \mathrm{~b}$ & $0.41 \pm 0.01 \mathrm{a}$ & $0.43 \pm 0.01 \mathrm{ab}$ & $0.46 \pm 0.01 \mathrm{~A}$ & $0.44 \pm 0.00 \mathrm{~A}$ \\
\hline & 10 & $0.45 \pm 0.02 \mathrm{ab}$ & $0.42 \pm 0.03 \mathrm{ab}$ & $0.44 \pm 0.02 \mathrm{ab}$ & $0.44 \pm 0.01 \mathrm{~A}$ & $0.45 \pm 0.02 \mathrm{~A}$ \\
\hline & 20 & $0.45 \pm 0.01 \mathrm{ab}$ & $0.43 \pm 0.03 \mathrm{ab}$ & $0.45 \pm 0.02 \mathrm{ab}$ & $0.45 \pm 0.02 \mathrm{~A}$ & $0.46 \pm 0.02 \mathrm{~A}$ \\
\hline \multirow{2}{*}{\multicolumn{2}{|c|}{ Factors $^{\mathrm{b}}$}} & \multicolumn{5}{|c|}{ Texture parameters } \\
\hline & & Hardness & Adhesiveness & Springiness & Gumminess & Cohesiveness \\
\hline \multicolumn{7}{|l|}{ Medium-fat yogurts } \\
\hline \multicolumn{2}{|l|}{ Storage time (ST) } & 0.007 & 0.129 & 0.169 & 0.002 & 0.255 \\
\hline \multicolumn{2}{|l|}{ LWPC incorporation } & 0.045 & 0.205 & 0.286 & 0.030 & 0.002 \\
\hline \multicolumn{2}{|c|}{$\mathrm{ST} \times \mathrm{LWPC}$ incorporation } & 0.732 & 0.184 & 0.259 & 0,905 & 0,625 \\
\hline \multicolumn{7}{|c|}{ Full-fat yogurts } \\
\hline \multicolumn{2}{|l|}{ Storage time (ST) } & 0.008 & 0.045 & 0.015 & 0.009 & 0.183 \\
\hline \multicolumn{2}{|l|}{ LWPC incorporation } & 0.000 & 0.000 & 0.757 & 0.000 & 0.696 \\
\hline \multicolumn{2}{|c|}{$\mathrm{ST} \times \mathrm{LWPC}$ incorporation } & 0.020 & 0.000 & 0.008 & 0.055 & 0.043 \\
\hline
\end{tabular}

Different letters indicate significant differences $(p<0.05)$. Small letters $(a, b)$ : differences amongst each texture parameter for medium-fat yogurts. Capital letters (A, B): differences amongst each texture parameter for full-fat yogurts. $p<0.05$ (in italics) indicates that factors produce statistically significant differences in dependent variables

1.5-C conventional, 1.5-15LWPC with $15 \mathrm{~g} / 100 \mathrm{~mL}$ LWPC incorporation, 1.5-30LWPC with $30 \mathrm{~g} / 100 \mathrm{~mL}$ LWPC incorporation, 9-C conventional, 9-30LWPC with $30 \mathrm{~g} / 100 \mathrm{~mL}$ LWPC incorporation

${ }^{a}$ Texture parameters (hardness, adhesiveness, springiness, and cohesiveness) of set yogurts during storage

${ }^{\mathrm{b}} p$ values of two-way ANOVA with factors interaction, for texture parameters in yogurts

(Lucey et al. 1998), the drainage and centrifugal methods evaluate the separation of whey from gels that may have suffered partial or total breakdown of the solid structure by the action of gravitational and centrifugal force respectively (Harwalkar and Kalab 1986; Guzmán-González et al. 1999). The other factor is related to the yogurt manufacture, including the various procedures or operational parameters adopted during production (temperature, $\mathrm{pH}$, agitation), the type of yogurt (set or liquid), the origin of the milk base(cow, sheep, or goat) (Salaün et al. 2005); embedded products (milk powder, whey protein concentrates) and the form of their incorporation (powder, liquid, with heat denaturation prior or subsequent to the milk mixture) (Lee and Lucey 2010); and lastly the biochemical composition of the formulations (total solids, protein content, and presence of polysaccharides) (Shah 2003).

The values for the yogurt syneresis can be observed in Fig. 3. As mentioned before full-fat yogurts showed the lower values of syneresis $(0.7 \%$ to $6.3 \%)$ despite their lower protein amount ( 3.21 and $3.58 \mathrm{~g} / 100 \mathrm{~g}$ ). This can be explained by the higher total solids content ( $18 \mathrm{~g} / 100 \mathrm{~g}$ in average) which is in the same order of magnitude of yogurts produced by Cais-Sokolinska and Pikul (2006), Li and Guo (2006) in fortified yogurt with powdered milk and Gomes (2010) for creamy yogurts. This observation is also supported by data of Amatayakul et al. (2006) and Jaros et al. (2002) who observed a reduction in syneresis with solids increase, indicating that above certain levels, the influence 


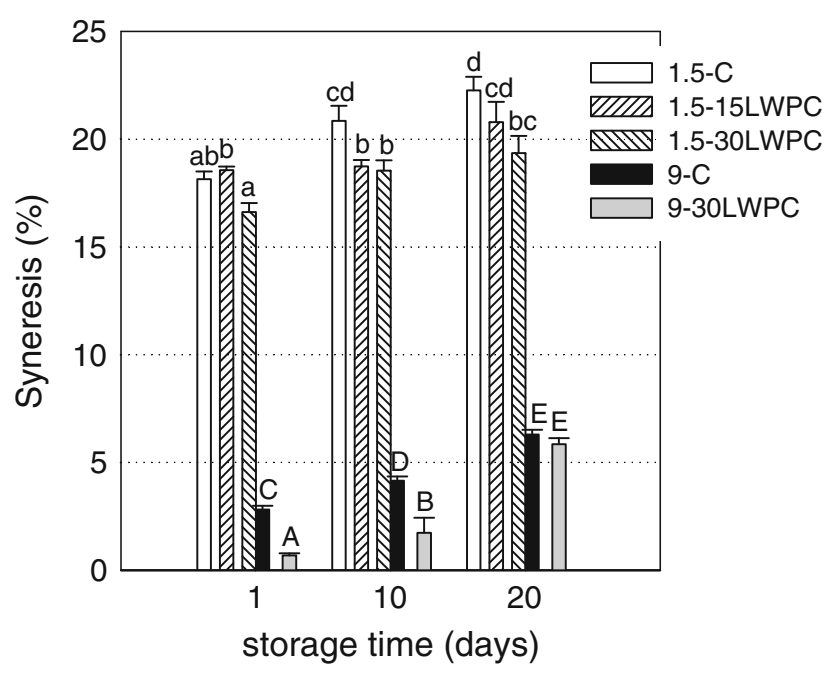

Fig. 3 Yogurt syneresis during storage. Medium-fat yogurts: 1.5- $C$ (conventional), 1.5-15LWPC and 1.5-30LWPC (with 15 and $30 \mathrm{~g} / 100 \mathrm{~g}$ LWPC incorporation respectively); full-fat yogurts: 9-C (conventional) and 9-30LWPC (with $30 \mathrm{~g} / 100 \mathrm{~g}$ LWPC incorporation). Different letters indicate significant differences $(p<0.05)$. Small letters: differences amongst syneresis for medium-fat yogurts. Capital letters: differences amongst syneresis for full-fat yogurts

of other factors over this parameter is no longer so obvious, particularly with regard to the quantity, shape, and type of protein added to the yogurt.

The small increase in total protein content in LWPC enriched yogurts (Table 4) may be responsible for the decrease in syneresis. However, this factor may not be exclusively responsible for these differences, since the total protein content of mediumfat yogurts ( 4.82 to $5.43 \mathrm{~g} / 100 \mathrm{~g}$ ) tested in this work is similar to the values used in previous studies which showed higher syneresis (Guzman-González et al. 1999; Katsiari et al. 2002; Amatayakul et al. 2006; Sodini et al. 2006). Li and Guo (2006) mention the excellent water retention properties of whey proteins when denatured prior to their addition to milk. They

Table $7 p$ values of two-way ANOVA with factors interaction, for syneresis, and viscosity in yogurts

\begin{tabular}{lll}
\hline Factors & \multicolumn{2}{l}{ Dependent variables } \\
\cline { 2 - 3 } & Syneresis & Viscosity \\
\hline Medium-fat yogurts & & \\
Storage time (ST) & 0.000 & 0.000 \\
LWPC incorporation & 0.000 & 0.004 \\
ST $\times$ LWPC incorporation & 0.011 & 0.000 \\
Full-fat yogurts & & \\
Storage time (ST) & 0.000 & 0.003 \\
LWPC incorporation & 0.004 & 0.000 \\
ST $\times$ LWPC incorporation & 0.000 & 0.016 \\
\hline
\end{tabular}

$p<0.05$ (in italics) indicates that factors produce statistical significant differences in dependent variables) noticed that in this case, the bonds between denatured whey proteins and caseins are more effective, promoting the formation of a protein network with smaller pores and greater ability to reduce syneresis.

It is believed that the main reasons for the different behaviors are: firstly the level of total solids, followed by the protein concentration and the ratio between the different protein types (casein and whey protein) present in the formulations and finally the form of whey protein added to the milk base (denatured or not).

Yogurt viscosity (Fig. 4) increased with fat content and with the amount of LWPC incorporated (Table 7). However, at the end of the storage time (20th day) no statistical differences were observed in the viscosity of yogurts with $1.5 \mathrm{~g}$ of fat/100 $\mathrm{g}$ (with or without LWPC incorporation). In the case of creamy yogurts, the viscosity differences between conventional and tested products observed at the tenth day, were maintained until the end of the storage time.

These results are in disagreement with those presented by Modler and Kalab (1983) and Sodini et al. (2005) who concluded that enriched products (with milk powder) or with higher levels of casein tend to produce more viscous gels with higher water retention capacity than products fortified with whey protein. It is important to notice that in the mentioned cases the incorporation of whey protein was performed in powder form and, protein denaturation occurred in the presence of milk caseins during yogurt pasteurization. As already referred, Li and Guo (2006) found that whey proteins previously denatured (which is the case of LWPC) added to milk caseins, favor the formation of bridges between then, leading to a

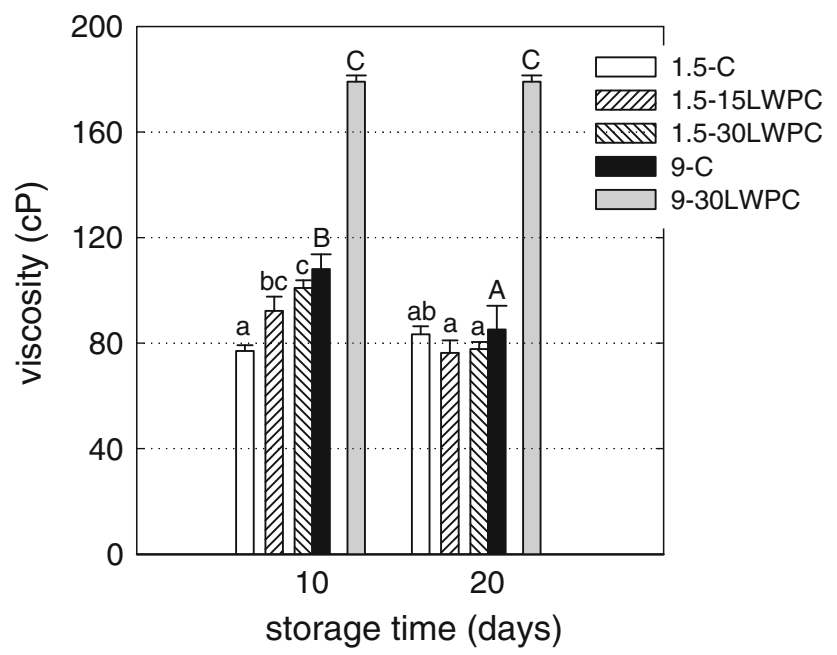

Fig. 4 Yogurt viscosity during storage. Medium-fat yogurts: $1.5-C$ (conventional), 1.5-15LWPC and 1.5-30LWPC (with 15 and $30 \mathrm{~g} / 100 \mathrm{~g}$ LWPC incorporation respectively); full-fat yogurts: 9-C (conventional) and 9-30LWPC (with $30 \mathrm{~g} / 100 \mathrm{~g}$ LWPC incorporation). Different letters indicate significant differences $(p<0.05)$. Small letters: differences amongst viscosity for medium-fat yogurts. Capital letters: differences amongst viscosity for full-fat yogurts 
narrow pored mixed casein/whey protein network, thus resulting in improved viscosity, consistency, and lower syneresis (Lee and Lucey 2010). Hence, it may be concluded that the replacement of WPC in powder form by LWPC is a less expensive alternative that simultaneously reduces syneresis and increases the yogurt viscosity.

No sensorial differences were detected between conventional and modified yogurts for the two types of products (medium fat and full fat). These results also indicate that the incorporation of LWPC at levels lower than $30 \mathrm{~g} / 100 \mathrm{~g}$ is a suitable form to increase the global process yield without the consumer being aware of the differences in the formulation.

\section{Conclusions}

It was concluded that LWPC incorporation in dairy products, can be very interesting not only concerning to the global process yield but also concerning to the functional properties of the products. Fresh cheese with LWPCs showed lower spontaneous syneresis and higher stability over time. This work also showed that the amount of LWPC incorporated in fresh cheese formulations is a very important parameter to consider for sensorial evaluation. Although, no statistical differences $(p<0.05)$ were detected between conventional and innovative products for textural properties (hardness, chewiness, and gumminess), higher amounts of LWPCs $(50 \mathrm{~g} / 100 \mathrm{~mL})$ reduced acceptability by panelists.

The fat content in yogurts was determinant for the functional LWPC performance in formulations. For medium-fat yogurts the use of LWPC did not produce significative differences in color $\left(\mathrm{L}^{*}, \mathrm{a}^{*}\right)$ and texture parameters neither during time nor between formulations. However, increasing LWPC in full-fat yogurts decreased hardness and gumminess. For both types of yogurts, syneresis increased during storage and decreased with LWPC incorporation presenting very low values for full-fat yogurts. Viscosity was improved with the addition of LWPCs especially for full-fat products. In the case of yogurts, no sensorial differences were detected between conventional and tested products.

The lower production costs and operations complexity in the manufacture of LWPCs as well as their performance in fresh cheese and yogurts functional properties, allows for its implementation in small to medium dairy production plants. The procedure avoids or reduces additional acquisition of conventional dry products such as skimmed, whole milk powder, or WPC used traditionally in the manufacture of these dairy products.

Acknowledgments The authors would like to thank Queijaria Serqueijos, SA (Portugal) for supplying bovine whey used in trials. Thanks are also due to Fundação para a Ciência e Tecnologia (FCT), Ministério da Ciência e do Ensino Superior, Operational Program of Science and Innovation 2010, for the Ph.D. grant (SFRH/BD/36645/2007).

\section{References}

Abrahamsen, R. K. (1979). Cheese making from milk fortified with ultrafiltrated whey protein concentrate. Milchwissenschaft, 34 (29), 1-4.

Amatayakul, T., Sherkat, \& Shah, N. P. (2006). Syneresis in set yogurt as affected by EPS starter cultures and levels of solids. International Journal of Dairy Technology, 59, 216-221.

AOAC (1997) Official methods of analysis of Association of Official Analytical Chemists. 16th ed. Volume II. 33 Dairy Products USA.

Baldwin, K. A., Baer, R. J., Parsons, J. G., Seas, S. W., Spurgeon, K. R., \& Torrey, J. S. (1986). Evaluation of yield and quality of cheddar cheese manufactured from milk with added whey protein concentrate. Journal of Dairy Science, 69, 2543-2550.

Banks, J. M., \& Muir, D. D. (1985). Effect of incorporation of denatured whey protein on the yield and quality of cheddar cheese. Journal Society of Dairy Technology, 38, 27-32.

Cais-Sokolinska, D., \& Pikul, J. (2006). Use of colour measurement to evaluate yoghurt quality during storage. Italian Journal of Food Science, 1(18), 63-71.

Damin, M. R., Alcântara, M. R., Nunes, A. P., \& Oliveira, M. N. (2009). Effects of milk supplementation with skim milk powder, whey protein concentrate and sodium caseinate on acidification kinetics, rheological properties and structure of nonfat stirred yogurt. LWT-Food Science and Technology, 42, 1744-1750.

Diaz, O., Pereira, C. D., \& Cobos, A. (2009). Aplicaciones de los concentrados y aislados de proteínas de lactosuero de la industria alimentaria. Alimentaria -Investigacion, Tecnologia e Seguridad, 400, 108-115.

Gauche, C. (2007). Polimerização de proteínas do soro de leite por transglutaminase e propriedades fisicas de iogurte elaborado após tratamento enzimático. Florianópolis, Brasil: Pós-Graduação em Ciência dos Alimentos.

Gomes, D. (2010). Incorporação de concentrados líquidos de proteínas de soro em produtos lácteos. Escola Superior Agrária de Coimbra. Master thesis, College of Agriculture-Polytechnic Institute of Coimbra, Coimbra, Portugal.

Guzmán-González, M., Morais, F., Ramos, M., \& Amigo, L. (1999). Influence of skimmed milk concentrate replacement by dry dairy products in a low fat set-type yoghurt model system. I: Use of whey protein concentrates, milk protein concentrates and skimmed milk powder. Journal of the Science of Food and Agriculture, 79, 1117-1122.

Harwalkar, V. R., \& Kalab, M. (1986). Relationship between microstructure and susceptibility to whey separation in yoghurt made from reconstituted nonfat dry milk. Food Microstructure, 5, 287-294.

Herrero, A. M., \& Requena, T. (2006). The effect of supplementing goat's milk with whey protein concentrate on textural properties of set-type yoghurt. International Journal of Food Science and Technology, 41, 87-92.

Hill, T., \& Lewicki, P. (2007). Statistics Methods and Applications. Tulsa, OK: StatSoft.

Hinrichs, J. (2001). Incorporation of whey proteins in cheese. International Dairy Journal, 11, 495-503.

IPQ. (1990). Leite e Produtos lácteos. Lisboa, Portugal: Edição Normas Portuguesas.

ISO 8586-2. (1994). Sensory analysis-General guidance for the selection, training and monitoring of assessors (Part 2: Experts) (1st ed.).

Jameson, G. W., \& Lelievre, J. (1996). Effects of whey proteins on cheese characteristics. Bulletin of the IDF, 313, 3-8.

Jaros, D., Rohm, H., Haque, A., \& Kneifel, W. (2002). Influence of the starter cultures on the relationship between dry matter content and physical properties of set-style yogurt. Milchwissenschaft, 57, 325-326. 
Jorge, C., Lobete, N. \& Pereira, C. (2006). Adição de proteínas de soro desnaturadas no fabrico de queijo. Leite I + D + T. N. ${ }^{\circ} 0,2-4$.

Kailasapathy, K., Supriadi, D., \& Hourigan, J. A. (1996). Effect of partially replacing skim milk powder with whey protein concentrate on buffering capacity of yoghurt. Australian Journal of Dairy Technology, 51, 89-93.

Katsiari, M. C., Voutsinas, L. P., \& Kondyli, E. (2002). Manufacture of yoghurt from stored frozen sheep's milk. Food Chemistry, 77, 413-420.

Korolczuk, J., \& Mahaut, M. (1991a). Effect of whey proteins and heat treatment of milk on the consistency of UF fresh cheese. Milchwissenschaft, 46, 435-437.

Korolczuk, J., \& Mahaut, M. (1991b). Consistency of acid fresh cheese. Role of whey proteins. Milchwissenschaft, 46, 153-156.

Lebeuf, Y., Lacroix, C., \& Paquin, P. (1998). Effet de l'incorporation des protéines du lactosérum dénaturées et microparticules dans le cheddar jeune. Le Lait, 78(3), 303-318.

Lee, W. J., \& Lucey, J. A. (2010). Formation and physical properties of yogurt. Asian-Australasian Journal of Animal Sciences, 23(9), 11271136.

Li, J., \& Guo, M. (2006). Effects of polymerized whey proteins on consistency and water-holding properties of goat's milk yogurt. Journal of Food Science, 71(1), 34-38.

Lucey, J. A. (2002). Formation and physical properties of milk protein gels. Journal of Dairy Science, 85, 281-294.

Lucey, J. A. (2004). Cultured dairy products: An overview of their gelation and texture properties. International Journal of Dairy Technology, 57, 77-84.

Lucey, J. A., Munro, P. A., \& Singh, H. (1998). Whey separation in acid milk gels made with glucono-delta-lactone: Effects of heat treatment and gelation temperature. Journal of Texture Studies, 29, 413-426.

Mahaut, M., \& Korolczuk, J. (1992). Effect of whey protein addition and heat treatment of milk on the viscosity of UF fresh cheese. Milchwissenschaft, 47, 157-159.

Modler, H. W., \& Kalab, M. (1983). Microestructure of yogurt stabilized with milk proteins. Journal of Dairy Science, 63, 430-437.

NP 1923 (1987). Iogurte Determinação do teor de matéria gorda Técnica de Gerber. Processo corrente. Comissão Técnica-32, $1^{\text {a }}$ edição. Portugal.

NP 2105 (1983). Queijos. Determinação do teor de matéria gorda. Técnica de Van Gulik. Processo corrente. Comissão Técnica$32,1^{\text {a }}$ edição, Portugal.

NP 3544 (1987). Queijos e queijos fundidos. Determinação do resíduo seco e do resíduo seco isento de matéria gorda. Comissão Técnica -32, 1a edição, Portugal.
NP 4146 (1991). Leite e produtos lácteos. Métodos de colheita de amostras. Comissão Técnica-32, $1^{\text {a }}$ edição, Portugal.

NP 469 (2002). Leites. Determinação da matéria gorda (técnica de Gerber). Processo corrente. Comissão Técnica-32, $3^{\text {a }}$ edição, Portugal.

NP 580 (1970). Leite. Determinação do resíduo seco e do resíduo seco isento de matéria gorda. Processo corrente. Comissão Técnica$32,1^{\text {a }}$ edição, Portugal.

NP 701 (1982). Iogurtes. Determinação da acidez. Comissão Técnica $-32,2^{\mathrm{a}}$ edição, Portugal.

NP 703 (1982). Iogurtes. Determinação do resíduo seco e resíduo seco isento de matéria gorda. Comissão Técnica-32, $2^{\text {a }}$ edição, Portugal.

Pérez-Munuera, M. E., \& Lluch, M. A. (1999). Study of some typical Spanish cheeses by scanning electron microscopy. Main microstructural modifications caused by freezing. Food Science and Technology International, 5(6), 515-521.

Phadungath, C. (2010). Basic measurements for food texture. http:// science.srru.ac.th/org/food_sci/result_civil_file/BasicMeasurement forFoodTexture.pdf. Accessed 16 August 2011.

Punidadas, P., Feirtag, J., \& Tung, M. A. (1999). Incorporating whey proteins into mozzarella cheese. International Journal of Dairy Technology, 52, 51-55.

Salaun, F., Mietton, B., \& Gaucheron, F. (2005). Buffering capacity of dairy products. International Dairy Journal, 15, 95-109.

Shah, N. P. (2003). Yogurt: The product and its manufacture. In B. Caballero, L. C. Trugo, \& P. M. Finglas (Eds.), Encyclopedia of food science and nutrition (2nd ed., Vol. 10). London: Academic Press, London.

Smithers, G. W., Ballard, F. J., Copeland, A. D., de Silva, K. J., Dionysius, D. A., Francis, G. L., et al. (1996). New opportunities from the isolation and utilization of whey proteins. Journal of Dairy Science, 79, 1454-1459.

Sodini, I., Montella, J., \& Tong, P. S. (2005). Physical properties of yogurt fortified with various commercial whey protein concentrates. Journal of the Science of Food and Agriculture, 85, 853859.

Sodini, I., Mattas, J., \& Tong, P. S. (2006). Influence of pH and heat treatment of whey on the functional properties of whey protein concentrates in yoghurt. International Dairy Journal, 16, 1464 1469.

Tamine, A. Y., \& Robinson, R. K. (1999). Yoghurt: Science and technology (2nd ed.). Boca Raton, FL: CRC Press.

Walstra, P., \& van Vliet, T. (1991). On the fractal nature of particle gels. In E. Dickinson (Ed.), Food polymers, gells and colloids. London: Royal Society of Chemistry. 